\title{
MEANING CONFIGURATION OF CULTURAL PRACTICES IN BALI AS A MODEL TO STRENGTHEN IDENTITY OF BALINESE PEOPLE
}

\section{Made Netra 1}

\section{Abstract}

This paper attempts to configure the meaning of cultural practices in the field of tradition in Bali including the cultural meaning of assertive, directive, expressive, commissive, and declaration that can be used as a model TO strengthen identity of Balinese people. In order to obtain valid data, participative observation taking the form of a focused group discussion was done in several locations in Bali. The data were then thoroughly analyzed based upon the theory of Natural Semantic Metalanguage originated by Wierzbicka (1999) with a model of Cultural Scripts proposed by Goddarad (2002). The result of analysis showed that: 1) cultural meanings found in verbal utterance of traditionally cultural practices in Bali could be derived from such functions of speech acts as: (a) assertive with cultural meanings of ngaturang 'to present and ngedengang 'to show '; (b) directive with cultural meanings of ngelungsur keslametan 'to ask for safety', nuturang 'to advise', ngundang 'to invite'; (c) expressive with cultural meanings of ampura 'to apologize' and suksma 'to thank'; (d) commissive with cultural meaning of mejanji 'to promise'; and (e) declaration with cultural meaning of mutusang 'to decide'; 2) Cultural meanings of Bali cultural practices could be configured using cultural scripts that can be used as a model to strengthen the identity of Balinese people.

Key word: configuration, meaning, cultural practice, cultural scripts, identity

${ }^{1}$ University of Udayana, Bukit Jimbaran Campus, Bali, Indonesia (dektih@yahoo.com) Received April 10 ${ }^{\text {th }}, 2015$; Revised May 20 ${ }^{\text {th }}$, 2015 ; Approved June $22^{\text {nd }}, 2015$

Bi-Monthly Double-Blind Peer Reviewed Refereed Open Access International E-Journal - Included in the International Serial Directories Indexed \& Listed at: Thomson Reuters Researcher ID: C-6767-2016, Google Scholar as well as in Directory of Abstract Indexing for Journals, U.S.A.

Scopus ID: 269F058D1B3EF38B; Impact Factor Evaluation [SJIF 2015 = 3.552]

International Research Journal of Management, IT and Social Sciences 


\section{Introduction}

Efforts to strengthen the identity of the community are in line with the national development of Indonesia that prioritizes the formation of character and national identity through cultural practices, especially in the realm of tradition concerning religion and customs. Bali as one of the ethnic groups in Indonesia is an ethnic retaining local wisdom values in the onslaught of globalization through cultural practices of Bali. The Balinese cultural practices contains a lot of cultural values, including meaning, norms, and local wisdom. The maintenance and strengthen of identity of Balinese people are done along with configuration model of cultural meaning. Configuration model developed by Goddard (1996, 2002) is called Cultural Scripts. This model is based on the configuration of cultural significance as a whole. This model is expected to strengthen the character and identity of Balinese people. Therefore, this study entitled "Meaning Configuration of Bali Cultural Practices as a Model to Strengthen the Identity of Balinese People" is given a priority to investigate

The description of the character and identity of Balinese people has been studied a lot previously by some researchers. However, there is a socio-cultural phenomenon and a fact that in Bali there is no a strengthening model yet to the Balinese identity and character of Balinese people accordingly. It gives an impact on the uncomprehensive documentation of cultural activities, such as cultural practices performed by Balinese people. The question that arises now is that how cultural meanings of local wisdom in Bali are maintained, dug up, and configured, so that it becomes a model for strengthening the identity and character of Balinese people. Therefore, this studies are urgently required.

\section{Literature Review}

This field research was conducted in the districts in Bali. As a matter of fact thatcultural practices are in a wide range and variation in Bali, which resulted in the diversity of cultural meanings significantly. Therefore, the primary data in this study were in the form of verbal utterances in Balinese tradition, in particular during the implementation of ritual offerings to God Almighty and wedding ceremony process. Meanwhile, secondary data were in the forms of archives, literature, and the report on problems being discussed. The method used to obtain

\footnotetext{
Bi-Monthly Double-Blind Peer Reviewed Refereed Open Access International E-Journal - Included in the International Serial Directories Indexed \& Listed at: Thomson Reuters Researcher ID: C-6767-2016, Google Scholar as well as in Directory of Abstract Indexing for Journals, U.S.A.

Scopus ID: 269F058D1B3EF38B; Impact Factor Evaluation [SJIF 2015 = 3.552]

International Research Journal of Management, IT and Social Sciences
} 
data was the method of participative observation (Bungin, 2001: 57; Moleong, 2000), which was supported by the technique of Focused Group Discussion (FGD). Furthermore, in-depth interviews were also applied to obtain further information. These in-depth interviews were conducted with informants first, then the results of these interviews were cross-referenced to such key informants society leaders. The sample of population was made with the technique of purposive sampling (Bungin, 2003). Furthermore, the meaning of cultural practices performed by Balinese was analyzed first. After that, the cultural meanings were configured by cultural scripts model to strengthen the identity and character of Balinese people.

\section{Research Methodology}

This section contains the meaning of cultural practices of Balinese people that is derived from functions of speech acts, such as assertive utterances, directive utterances, expressive utterances, commissive utterances, and declaration utterances. Then, the cultural meanings are configured with a model of cultural scripts.

\subsection{Assertive Cultural Meaning}

Assertive functions are functions of utterances that binds speakers to the truth of what is said. Assertive utterance is a statement of something that binds speakers at a truth. It is also a speech stating a very strong belief expressed by speaker. The essence of assertive speech in Bali which is becoming identity and character of Balinese people can be explicated as follows.

People think like this:

When someone knows something, it would be good if this person could state its existence

And when one knows the truth, it is better if this person can tell it to others

The essence of the meaning of this assertive can be seen in the following text

(1) Puniki krama subak druwe prasida rauh tangkil ring ajeng palungguh I Ratu, ngaturang sembah pangubhakti melarapan antuk bhakti pangusaba emping meruntutan bhakti suci dandanan maguling babi sajangkapnya katur ring singgih Bhatara

Bi-Monthly Double-Blind Peer Reviewed Refereed Open Access International E-Journal - Included in the International Serial Directories Indexed \& Listed at: Thomson Reuters Researcher ID: C-6767-2016, Google Scholar as well as in Directory of Abstract Indexing for Journals, U.S.A. Scopus ID: 269F058D1B3EF38B; Impact Factor Evaluation [SJIF 2015 = 3.552] International Research Journal of Management, IT and Social Sciences 
'Currently the members of Subak come to prostrate before you praying and devoting with duck meat and suckling pig completed with the offerings'

The cultural meaning of the text above is to show the existence of an organization in which members of Subak reveal the truth about the existence and compactness to bow down and pray to God Almighty. Lexicon representation that refers to this meaning is ngaturang 'to present'. In addition, the representation of assertive meaning can be seen in the following text which implies ngedengang 'to show', as shown in the following text.

(2) Sadurunge titiang ngelantur matur, matur-atur ring penglingsir titiang sareng sami iriki, lugrayang titiang ngaturang pangastuti ring Ida Sanghyang Widi antuk paramarta wiadin tetujon titiang rauh meriki jagi uningayang titiang dumun sapa sira sane rauh meriki.

'Before I deliver it further to the parents and elders concerned here, allow me to deliver to worship and praise to God Almighty for His blessings that I can deliver and convey the purpose of my arrival here, and let me also to tell those who come along with me in meeting today '

The way Balinese people communicate in cultural practices hints:

Ngedengang 'to show'

People think like this:

When I think of something, it would be better if I can show them to others

When I have something, it would be better if I can show them to others

When I do something, it would be better if I can show them to others

\subsection{Directive Cultural Meaning}

Directive function is a function of utterances made by speakers with the intention that the hearers could perform the acts implied in the utterance. The directive utterances are intended to express the speaker's expression of attitudes towards actions to be taken by the hearer. In other words, this directive function of utterance is to express the intention of speakers (desires, hopes, and feelings) as an utterance or attitude expressed and used as a reason for action by hearers. Therefore, the core of the directive meaning can be explicated as follows:

Bi-Monthly Double-Blind Peer Reviewed Refereed Open Access International E-Journal - Included in the International Serial Directories Indexed \& Listed at: Thomson Reuters Researcher ID: C-6767-2016, Google Scholar as well as in Directory of Abstract Indexing for Journals, U.S.A.

Scopus ID: 269F058D1B3EF38B; Impact Factor Evaluation [SJIF 2015 = 3.552]

International Research Journal of Management, IT and Social Sciences 
People think like this:

When I feel something and want someone to do something

It would be better if I say something like this to this person:

"I want you to do this

I think you will do this because of it"

Directive utterances have various meanings according to the context of speaking and Balinese culture, such as nglungsur keslametan 'to asks for safety' embodied in the following text

(3) Kenak mangkin singgih Bhatara ngaksi saha nampenin baktin krama subak sami,singgih Bhatara mangkin ngayab, natab sari nyumput sari sedaging bakti. Lungsur titiang mangkin swecan singgih Bhatara mangda pantun sane jagi katandur mangda prasida maurip

'We are witnessing once you accept their offerings. Their goal is to deliver to this thanksgiving ceremony so that you always give grace to rice seeds that will be planted in the fields of life as it should, is not affected by pests and diseases, and enough water, so the growth becomes solid content '

In addition, the representation of the meaning of the directive can be nuturang 'to advise' and ngundang 'to invite', as shown in the following text

(4) Diastun sampun wenten cihna, titiang anak manusa masih tan kenten ya......,niki anak berat pisan niki, tan kenten ya...Titiang nunas mangda I made mangda gelindeng-gelindengange meriki, tan kenten ya...... Mangda titing tan jempulunganga nyanan. Manut sampun, tan kenten ngih, ngiring sareng-sareng tureksa.

'Although there has been a clue, I am also a human right, it is very difficult, isn't it? I ask that I Made should come to visit her in here, shouldn't she? in order not to be blamed later on, is it OK?. Let us keep together'.

The above text (4) indicates that the identity of people of Bali in terms of advising and inviting can be configured as follows

nuturang 'to advise'

People think like this:

Bi-Monthly Double-Blind Peer Reviewed Refereed Open Access International E-Journal - Included in the International Serial Directories Indexed \& Listed at: Thomson Reuters Researcher ID: C-6767-2016, Google Scholar as well as in Directory of Abstract Indexing for Journals, U.S.A.

Scopus ID: 269F058D1B3EF38B; Impact Factor Evaluation [SJIF 2015 = 3.552]

International Research Journal of Management, IT and Social Sciences 
Something good will happen if someone can do something nice for everyone

If not, something bad will happen

Therefore, this person will say something like this:

"You can do this to other people again"

ngundang 'to invite' in Balinese, however, is different. Ngundang 'to invite' is used when people of Bali do activities for a joy. See the following explication.

ngundang 'to invite'

Other people think like this:

When something good happens to someone, it would be nice if someone else can do something

Therefore, one can think of something, like this:

'I would better to tell this to others

If not, other people cannot do something and that something bad will happen to me'

\subsection{Expressive Cultural Meaning}

Expressive function is a function of utterance made by speakers with the intention that the utterance can be interpreted as an evaluation of the things mentioned in a speech, for example, apologizing and thanking. Here's the explication of Balinese cultural scripts related to expressive meaning

People think like this:

It is a good thing if someone wants other people to know what the people are thinking

Ii is a good thing if someone wants other people to know what the people are feeling

Expressive meaning is to show humility represented by ampura'to apologise' and suksma 'to thank'. Consider the following text

(5) Singgih nawegang Ratu Bethara sane melingga melinggih iriki ring Pura Bedugul, inggih punika Ratu Bethara Dewi Danuh, Ratu Bethara Dewi Sri, lan Bhetara Ibu Pertiwi

'Oh my God, we apologise to You within your manifestation as Goddis who occupies in Bedugul temple, namely Bathara Dewi Danuh (the God of Lake), Dewi Sri (the God of prosperity) ,and Dewa Bumi (the God of Earth)'

Bi-Monthly Double-Blind Peer Reviewed Refereed Open Access International E-Journal - Included in the International Serial Directories Indexed \& Listed at: Thomson Reuters Researcher ID: C-6767-2016, Google Scholar as well as in Directory of Abstract Indexing for Journals, U.S.A.

Scopus ID: 269F058D1B3EF38B; Impact Factor Evaluation [SJIF 2015 = 3.552]

International Research Journal of Management, IT and Social Sciences 
The way Balinese people apologize and thank can be configured as follows

ampura 'to apologise'

People think like this:

When someone does something that is not good and therefore something bad happens to someone else, it would be nice if someone says something like this:

"I want you to know what I feel at this moment

I say sorry like this "

If not, something worse will happen again

suksma 'to thank'

People think like this:

When others have done things and therefore someone pick something good, it would be nice if this person can do something good to others

It is not bad if someone could say something like this:

"I'm not grateful like this

I am grateful to this

I want you to know what I feel"

At the same time, when the time comes, this person will do something good for others.

Therefore, something good may happen to others

\subsection{Commissive Cultural Meaning}

Commissive meaning is the meaning of utterance that binds speakers to implement what was mentioned in their utterances, such as promising. Cultural scripts related to the commissive utterance can explicated in a high-level script, as shown below

People think like this:

It is a good thing that if someone says something, another person can do something like what this person is saying

Something is not good if someone does not do something like what this person is saying

Bi-Monthly Double-Blind Peer Reviewed Refereed Open Access International E-Journal - Included in the International Serial Directories Indexed \& Listed at: Thomson Reuters Researcher ID: C-6767-2016, Google Scholar as well as in Directory of Abstract Indexing for Journals, U.S.A.

Scopus ID: 269F058D1B3EF38B; Impact Factor Evaluation [SJIF 2015 = 3.552]

International Research Journal of Management, IT and Social Sciences 
Commissive cultural meaning is representedby mejanji 'to promise', as shown in the following text.

(6) Wantah kadi asapunika, malih jebos titiang taler ngelungsur upakara-upakarairiki, mangda biang-biang iriki masadu ajeng.

'That is all we can say, we will also have kinds of offerings. We do hope that mothers could have a face to face meeting discussing this matter'

The promise is one of the Balinese identities performed by Balinese people in daily life tradition. They have a unique way in terms of promise. The way how Balinese people promise can be configured as follows

mejanji ' to promise'

People think like this:

At that time, someone said something to someone else

At the same time, one can do something

If not, something bad can happen to someone

Therefore, it would be good if someone can do something like what this person is saying. When someone does not do things according to what people have to say, something bad can happen. Therefore, it would not be good if someone does not do anything like what this person is saying

\subsection{Declaration Cultural Meaning}

A declaration is a meaning of utterance implied by speaker with the intention of creating something new (status, existence, condition, and so forth). Cultural meanings associated with the declaration can be paraphrased as follows.

People think like this:

When someone knows something, it would be better if this person could state its existence And when someone knows the truth, something new can happen accordingly. Representation of cultural meaning associated with declaration utterance in Bali is mutusang 'to decide'. Consider the following text

Bi-Monthly Double-Blind Peer Reviewed Refereed Open Access International E-Journal - Included in the International Serial Directories Indexed \& Listed at: Thomson Reuters Researcher ID: C-6767-2016, Google Scholar as well as in Directory of Abstract Indexing for Journals, U.S.A.

Scopus ID: 269F058D1B3EF38B; Impact Factor Evaluation [SJIF 2015 = 3.552]

International Research Journal of Management, IT and Social Sciences 
(7) sane mangkin titiang ngelinggihang Dewa Nini

santukan bulih sane kaurit oleh I krama sampun prasida maurip

'Now members of Subak makeDewa Nini in the respective rice fieldsbecause the stocked seeds are now grown into seedlings'

(8) Napi daging wicara I wawu sampun kamanah antuk titiang riantuk daging tetuak nyane tuni sampun titiang piragi saking guru rupakan ipune. Mangkin sampun tatas antuk titiang unteng rauh semeton titiang sakeng kaler asapunika. Ring tepengan mangkin, titiang anggene reraman ipune nenten pisan bisa ngepasan pisan, yening keletang titiange, nanging ipun sane gomboh, yening gombohang titiang pianak titange, ipun sane kelet.

'The purpose of coming to see us here was well noted. What was being presented and delivered by parents and family of Buleleng regency in the meeting was well understood.In this case, being a parents, we do not ensure about it yet, and therefore the decision has not been made yet, either. It is really difficult. However, it depends much upon our daughter's decision. We just follow what she really wants to do. Thus, her decision is ours'

Balinese identity is shown as well with the act of deciding something. In terms of deciding something, Balinese people have the unique way that can be configured as follows.

mutusang 'to decide'

People think like this:

When something good happens, it would be nice if someone could say something to someone else. At the same time, when other people determine something bad happens, it would be good if someone else can do something only once. Therefore, Something bad no longer happens and something new can happen

\section{Conclusion}

After having studied the meanings of Balinese cultural practices in the field of tradition, some conclusions can be drawn, as follows:

\footnotetext{
Bi-Monthly Double-Blind Peer Reviewed Refereed Open Access International E-Journal - Included in the International Serial Directories Indexed \& Listed at: Thomson Reuters Researcher ID: C-6767-2016, Google Scholar as well as in Directory of Abstract Indexing for Journals, U.S.A.

Scopus ID: 269F058D1B3EF38B; Impact Factor Evaluation [SJIF 2015 = 3.552]

International Research Journal of Management, IT and Social Sciences
} 
1) The cultural meaning found in verbal utterance of traditionally cultural practices in Bali could be derived from such functions of speech acts as: (a) assertive with cultural meanings of ngaturang 'to present' and ngedengang 'to show '; (b) directive with cultural meanings of ngelungsurkeslametan 'to ask for safety', nuturang 'to advise', ngundang 'to invite'; (c) expressive with cultural meanings of ampura 'to apologize' and suksma 'to thank'; (d) commissive with cultural meaning of mejanji 'to promise'; and (e) declaration with cultural meaning of mutusang 'to decide';

2) Cultural meanings of Bali cultural practices could be configured using cultural scripts that can be used as a model for strengthening the identity of Balinese people.

\section{Acknowledgement}

First of all, I would like to thank God the Almighty for His blessing that this article entitled "Meaning Configuration of Cultural Practices in Bali as Model for Strengthening Balinese Identity" can be completed well in time. We also thank the followings who did help in the process of completing the article in forms of funding including: Rector of Udayana University, Dean of Faculty of Letters and Cultures of Udayana University, The Chairman of the Institute for Research and Community Services of Udayana University, The Head of English Department, Faculty of Letters and Cultures of Udayana University, The informant as and key informants coming from Buleleng and Gianyar Regencies, Bali, Indonesia. Last but not least, we deliver sincere gratitude to parties concerned. All comments and suggestions are highly appreciated.

\section{References}

[1] Bach, K. dan Robert M. Harnish. 1979. Linguistic Communication and Speech Acts. London: The MIT Press.

[2] Bauman, R. \& Joel Sherzer. 1974. Exploration in the Ethnography of Speaking. Cambridge: Cambridge University Press.

[3] Bungin, Burhan. 2003. Analisis Data Penelitian Kualitatif. Pemahaman Filosofis dan Metodologis ke Arah Penguasaan Model Aplikasi. Jakarta: PT Raja Grafindo Persada

[4] Goddard, C. 1994. Cross Linguistic Syntax from A Semantic Point of View (NSM Approach). New England: New England University Press.

[5] Goddard, C. 1997. "Semantic Theory and Semantic Universal" Dalam Cliff Goddard and A. Wierzbicka (eds), from Semantic and Lexical Universals: Theory and Empirical Findings. Amsterdam/Philadelphia: Benjamins, 7--29.

Bi-Monthly Double-Blind Peer Reviewed Refereed Open Access International E-Journal - Included in the International Serial Directories Indexed \& Listed at: Thomson Reuters Researcher ID: C-6767-2016, Google Scholar as well as in Directory of Abstract Indexing for Journals, U.S.A.

Scopus ID: 269F058D1B3EF38B; Impact Factor Evaluation [SJIF 2015 = 3.552]

International Research Journal of Management, IT and Social Sciences 
[6] Goddard, C. 2000. Semantic Analysis: A Practical Introduction. Oxford: Oxford University Press.

[7] Goddarad, C. 2003. "Directive Speech Acts in Malay: Ethnopragmatic Perspective". inSpecial Issue on Intercultural Communication. Edited by Christine Beal. 2003

[8] Moloeng, Lexy J. 1994. Metodologi Penelitian Kualitatif. Bandung: PT Remaja Rosdakarya.

[9] Sudaryanto. 1993. Medode dan Aneka Teknik Analisis Bahasa: Penganlar penelilianWahana Kehudayaan Secara Linguilis. Yogyakarta: Duta Wacana University Press.

[10] Wierzbicka, A 1991. Cross-Cultural Pragmatics. The Semantics of Human Interaction. Berlin and New York: Mouten de Gruyter

[11] Wierzbicka, A. 1992. Semantics, Culture, and Cognition. New York and Oxford: Oxford University Press.

[12] Wierzbicka, A. 1996. Semantics Primes and Universals. Oxford and New York: Oxford University Press.

[13] Wierzbicka, A 1999. Emotions Across Languages and Cultures: Diversity and Universals. Cambridge: Cambridge University Press

\section{Biography of Author}

\begin{tabular}{|l|l|}
\hline & $\begin{array}{l}\text { Dr. I Made Netra, SS, M. Hum is a Doctor in Linguistics in Udayana } \\
\text { University, a lecturer at English Department of Under Graduates } \\
\text { Program and Linguistics of Post Graduates Study Programs in } \\
\text { Udayana University. Subjects taught are Introduction of Micro and } \\
\text { Macro Linguistics, English Pragmatics and Discourse Analysis, } \\
\text { Functional Text Analysis, Translation in Different Registers, Theory } \\
\text { of Linguistics (Semantics). }\end{array}$ \\
$\begin{array}{l}\text { Dr. I Made Netra, S.S., M.Hum is active in doing researches in } \\
\text { Linguistics funded by both Higher Education of Ministry of National } \\
\text { Education and PNBP of Udayana University. His research interest is } \\
\text { macro linguistics including ethnopragmatics (natural semantic } \\
\text { metalanguage and cultural scripts) and discourse analysis. }\end{array}$ \\
$\begin{array}{l}\text { Dr. I Made Netra, S.S., M.Hum concerns much in developing } \\
\text { researches in macro linguistics synthesizing language and culture, } \\
\text { language and ecology, language and society, language and gender, } \\
\text { and so forth. So that he has ever achieved an award of the best } \\
\text { researcher in the field of Humanities from DP2M of Higher Education } \\
\text { of ministry of national education of republic of Indonesia. He won } \\
\text { several national strategic research grants in 2008 and Udayana } \\
\text { University Invention Research Grant in 2014 and 2015. }\end{array}$ \\
\hline
\end{tabular}

Bi-Monthly Double-Blind Peer Reviewed Refereed Open Access International E-Journal - Included in the International Serial Directories Indexed \& Listed at: Thomson Reuters Researcher ID: C-6767-2016, Google Scholar as well as in Directory of Abstract Indexing for Journals, U.S.A.

Scopus ID: 269F058D1B3EF38B; Impact Factor Evaluation [SJIF 2015 = 3.552]

International Research Journal of Management, IT and Social Sciences 